Pobrane z czasopisma Wschód Europy http://journals.umcs.pl/we

Data: 26/04/2023 17:00:15

D0I:10.17951/we.2019.5.1.13-32 Wschód Europy • Восток Европы • East of Europe vol 5, 1 / 2019

Александра Глухова

ORCID: https://orcid.org/0000-0002-3894-3229

Воронежский государственный университет, Россия

\title{
Новый авторитаризм в XXI веке: мировые тенденции и российский саse study
}

\begin{abstract}
A вторитарные тенденции в современном мире становятся все более заметным явлением, о чем свидетельствуют не только статьи и книги ученых, но и тематика международных конференций, посвященных их обсуждению. «Возвращение авторитарных великих держав», «авторитарный откат» были зафиксированы исследователями уже в конце так называемых «нулевых» годов. «Начало авторитарного столетия? 1918 - 1938 - 2018» ${ }^{1}-$ таково название международной конференции, прошедшей в сентябре 2018 г. в Вене. Тематика конференции адресована двум примечательным датам, маркирующим переломные события в политической истории XX века, и современной ситуации в мире, характеризующейся ростом авторитарных тенденций. Целью настоящей статьи является выявление природы нового авторитаризма, включая анализ породивших его факторов, а также специфику российского политического режима, причины его устойчивости и риски дестабилизации.

Классическими работами, посвященными феномену авторитаризма, являются труды Х.Линца, С.Левицки и Л.Уэя². В 2000-е годы, по мере затухания третьей демократической волны (С.Хантингтон), появились дополнительные объекты для исследования. Факт авторитарного перерождения ряда политических режимов в этот период обстоятельно исследовала американский политолог М.Оттауэй${ }^{3}$. Она настаивала на более точной идентификации такого рода режимов, называя их не полудемократическими (т.е. не завершившими по тем или иным причинам переход к либеральной демократии в ходе транзита), а полуавторитарными, по-

1 Der Beginn eines autoritaeren Zeitalters? Die international Tagung «1918 - 1938 - 2018. Dawn of an Authoritarian Century?» / Conference, 5-7 September 2018 // http://www.bdb.de/ mediathek/275781/der- begin-eines-autoritaeren-zeitalters, датаобращения: 14.10.2018.

2 J.J. Linz, Totalitarian and Authoritarian Regimes, London2000, 343 p.; S. Levitsky., L Way, Competitive Authoritarianism: Hybrid Regimes after the Cold War, UK2010, 517 p.

3 См.: M. Ottaway, Democracy Challenged: The Rise of Semi-Authoritarianism, Washington2003.
\end{abstract}


лагая это качество сознательным выбором правящих элит. Т.Карозерс выделил факторы, сделавшие возможным авторитарный политический сдвиг ${ }^{4}$. Болгарский политолог И.Крастев одним из первых обратил внимание на парадоксальную природу нового авторитаризма, проанализировав его на примере посткоммунистической России ${ }^{5}$. Российский историк И.Яжборовская и польский социолог М.Гдула на примере политического процесса в Польше (после 2015 г.) продолжили исследование «нового авторитаризма», выделив его существенные признаки и факторы устойчивости к внешним и внутренним вызовам ${ }^{6}$. Наконец, группа немецких ученых во главе с В.Меркелем предложили теоретическую модель исследования авторитарного режима и его разложения, опираясь на метод исторического институционализма как наиболее релевантный предмету исследования 7 . Попытаемся вкратце обрамить наиболее важные черты феномена нового авторитаризма, включая факторы, благоприятствовавшие его возникновению.

\section{Авторитарные искушения в XXI веке}

В числе первых на признаки формирующегося авторитарного тренда в начале XXI века указал выдающийся европейский интеллектуал Р.Дарендорф. В одной из своих последних работ он предостерегал исследователей от недооценки «крадущегося авторитаризма» как современной формы угрозы демократии и свободе, ограничения либеральных порядков. «На множестве больших и маленьких путей к нам подкрадывается авторитаризм, который в своих проявлениях не отождествим с тоталитарными эксцессами XX столетия, но серьезно вредит конституции свободы, - писал Р.Дарендорф. - Он даже принял форму модели, которую Жан Бурума обозначил как „авторитарную технократию”. Ее истоки можно найти в Азии, в частности, в Сингапуре. Эта форма ограничения либеральных порядков обещает „благосостояние без политики”, т.е. экономический рост без активного гражданского общества. Но публичные интеллектуалы лишь спорадически делают этот крадущийся авторитаризм темой своего исследования» ${ }^{8}$.

Проблема авторитарного отката, возникающего в процессе общественной трансформации, тревожила и других известных интеллектуалов. В частности, автор концепции «волн демократизации» С.Хантингтон ${ }^{9}$ также обращал внима-

4 Т. Карозерс, Трезвый взгляд на демократию, „Proetcontra” 2005, № 1 (28), с. 74.

5 И. Крастев, Парадоксы нового авторитаризма,„Proetcontra” 2011, № 3-4 (52), с. 96-105.

6 И. Яжборовская, Польша 2015-2016 г2. Хроника неоавторитарного реванша, „Политические исследования" 2016, №5, с. 49-65; M. Gdula, Nowyautorytaryzm, Warszawa2018, ss. 112.

7 Cм.: J. Gerschewski, W. Merkel, A. Schmotz, Ch. H. Stefes, D. Tanneberg, Warum uberleben Diktaturen, [in.] Politische Vierteljahresschrift, Sonderheft 47, 2012, s. 1-26.

8 R. Dahrendorf, Versuchungen der Unfreiheit (Die Intellektuellen in Zeiten der Prufung), Munchen2006, s. 214.

9 См.: С. Хантингтон. Третья волна. Демократизация в конще ХХ века(пер. с англ.), Москва 2003. Образ волны как природного явления, использован автором именно в силу ее двухфазовой динамики, т.е. прилива и отлива. 
ние на то, что за каждым приливом демократической волны обычно следовал откат, обретавший различные политико-идеологические формы, но неизменно отличавшийся авторитарным содержанием. Откат третьей волны, по его мнению, мог породить различные формы авторитаризма - авторитарный национализм, религиозный фундаментализм, олигархический авторитаризм, популистскую диктатуру и т.д. В числе факторов, способствовавших такому попятному движению, С.Хантингтон называл недостаточную укорененность демократических ценностей среди ключевых групп элиты и широкой общественности; экономический кризис, обостряющий социальный конфликт по поводу распределения ресурсов; рост терроризма и повстанческих движений, разрушающих нормы закона и порядка, и т.д. ${ }^{10}$

Книга С.Хантингтона была написана в конце 1980-х - начале 1990-х годов, когда очередной глобальный процесс демократизации, названный им «третьей волной», только разворачивался. Она стала предварительной попыткой объяснения демократических транзитов и их возможных последствий. Сегодня появились новые исследования, подтверждающие и развивающие его концепцию. В их числе - масштабный труд немецкого политолога В.Меркеля, посвященный разработке теории системной трансформации XX века, и в первую очередь третьей волне демократизации ${ }^{11}$.

Особенно важным было выявление факторов, сделавших возможным откат от демократического маршрута. Одним из первых эту проблему попытался решить Т.Карозерс, по мнению которого, уже в середине так называемых «нулевых годов» стал ясно вырисовываться авторитарный политический тренд. Речь шла о недемократических порядках, утверждавшихся на территории бывшего СССР (на «постсоветском пространстве»); о политической нестабильности, росте конфликтов и делегитимации демократических институтов в Южной Америке. В Восточной Азии, включающей Китай, Северную Корею, Вьетнам, Бирму, Лаос и Сингапур, сохранялось авторитарное правление без шансов серьезных перемен. В десятках африканских стран, некогда вступивших на путь демократизации, политический плюрализм сменился разрушительными гражданскими войнами. Арабский мир после волны массовых политических протестов («Арабская весна» 2011 г.), сместившей правившие десятилетиями диктаторские режимы, получил взамен победу исламистов на свободных конкурентных выборах, а затем вмешательство армии (Египет) с целью наведения порядка. Результатом стало новое противостояние традиционалистов и «модернистов», т.е. ортодоксов и приверженцев внедрения современных форм организации общественно-политической жизни ${ }^{12}$.

10 Ibidem, c. 310-311.

11 См.: W. Merkel, Systemtransformation. Eine Einfuhrung in die Theorie und Empirie der Transformationsforschung, Wiesbaden 2010.

12 Т. Карозерс, Трезвый взгляд на демократию, „Proetcontra” 2005, № 1 (28), с. 74. 
Эти перемены стали результатом действия разнообразных факторов, в том числе и уникальных применительно к каждому региону. Однако все вместе они создали кумулятивный эффект и неблагоприятный контекст, препятствующий прогрессу демократии и облегчающий авторитарные практики. Главным фактором стало сохранение и даже омоложение авторитарных сил и структур во многих демократизирующихся странах. Бездействуя в период падения диктаторских режимов, эти силы вновь вышли на авансцену политической жизни вследствие поверхностного характера преобразований. Несмотря на свободные выборы, создание новых конституций, возраставший интерес гражданского общества к политике и началу реформ государственного управления, политическая повседневность лишь формально была плюралистической. «Процесс изменений во многих случаях не затрагивал институты - они сопротивлялись, приспосабливались, сохраняя наследие авторитарного режима и его способ мышления; ряд акторов также оказался не затронут новыми веяниями: структуры госбезопасности, вооруженные силы, государственные предприятия с их сетью неформальных коррупционных связей» ${ }^{13}$. На «поразительную живучесть» старых социальных структур в бывших социалистических странах, напоминающих ситуацию в Европе после Первой мировой войны, обращал внимание и Р. Дарендорф. «Мне становится дурно при мысли о команде, состоящей из военных чинов, экономистов-плановиков и расистов, которых могут привести к власти лишившиеся своего места в обществе и охваченные разочарованием группы», писал он в начале 1990 -х годов ${ }^{14}$.

В числе ключевых факторов, способствовавших авторитарному тренду, следует назвать слабую социально-экономическую эффективность молодых демократий, личную незащищенность людей, возлагавщих надежды на «сильную руку». Разочарование граждан новых демократических государств в своих правительствах повлекло потерю веры в демократию, обернулось нестабильностью и политическими конфликтами.

С другой стороны, экономические успехи стран с авторитарным правлением «работают» на их легитимацию и становятся неблагоприятным фактором для глобального распространения демократии. Впечатляющим примером успешного социально-экономического развития стала китайская модель, а также высокие показатели экономического роста во Вьетнаме, России и Казахстане в 2000-е годы. В двух последних странах экономический рост обеспечили высокие цены на нефтегазовое сырье, в силу чего повторить их опыт в отсутствие подобных же ресурсов в других странах невозможно. Однако эти успехи подпитывают веру в то, что авторитаризм обеспечивает лучшие возможности экономического развития, нежели демократия.

13 Ibidem, c. 74.

14 Р. Дарендорф, Размышления о революиии в Европе (В письме некоему господинув Варшаве), „Путь. Международный философский журнал” 1994, № 6, с. 101. 
Благоприятным для авторитарных практик выглядит и внешний, международный контекст. Репутация Запада как защитника и инициатора демократизации была подорвана свержением режимов в ряде стран Ближнего Востока (в Афганистане, Ираке, Ливии), ведущую роль в котором играли США. С другой стороны, терпимое отношение западных правительств к нарушению прав человека в странах-союзниках (например, в Саудовской Аравии), говорит о двойных стандартах: принципы демократии приносятся в жертву взаимовыгодному сотрудничеству с экспортерами энергетического сырья.

К характерным чертам нового авторитаризма относятся:

- отрицание плюралистического характера общества и политики как конкурентной борьбы за власть, трактовка ее в качестве запретного вида деятельности, нуждающегося в санкционировании властью;

- популистские апелляции к народу, к поддержке большинства, обеспечивающей правящей партии и режиму в целом широкие возможности для ограничения политических и гражданских прав и свобод;

- активизировавшийся поиск идеологических обоснований политического курса (вопреки традиционному авторитаризму, как правило, деидеологизированному);

- попытки использования традиционалистских идеологических обоснований с опорой на религию либо на героическое историческое прошлое;

усиливающийся контроль над средствами массовой информации, прежде всего Интернетом;

- активное использование судопроизводства и правоприменительной практики в подавлении сопротивления активистов общественных групп (длительное досудебное задержание, большие тюремные сроки, принуждение к выезду из страны и т.д.);

- игнорирование резолюций международных организаций, осуждающих использование авторитарных практик (при сохранении в них формального членства);

- обвинение Запада и в целом внешних сил в организации и осуществлении заговоров с целью свержения власти и т.д.

Таким образом, совершающийся отход от демократического маршрута (даже при сохранении популистской («демократической») риторики у правящих элит) свидетельствует не только о неблагоприятных объективных предпосылках для демократического строительства, но и о слабости общественно-политических сил, призванных выступать в качестве его главных субъектов. Новым авторитариям удалось легитимировать свою власть и убедить общество в том, что политические свободы могут быть принесены в жертву экономическому процветанию/благополучию. 


\section{Новый авторитаризм по-российски}

Российский политический режим, сложившийся в результате вооруженного противостояния внутри политического класса и разрешившийся насильственным разгоном парламента - Верховного Совета, получил свое правовое оформление и закрепление в Конституции 1993 года. Сама конфигурация российской власти, закрепленная конституционными нормами, вызывала обоснованную критику как отечественной, так и зарубежной общественности. Термин «выборное самодержавие» стал расхожим в определении полномочий действовавшего на тот момент президента Б.Ельцина ${ }^{15}$. Непопулярная в обществе и драматичная по своим последствиям война в Чечне привела к резкому снижению его рейтинга доверия. Одновременно в стране сохранялись независимые СМИ, включая телеканалы, существовала сильная левая и демократическая оппозиция в Государственной думе, оставались влиятельными региональные политические элиты. Отставка Б.Ельцина в канун нового 2000 года давала стране шанс продвинуться вперед в деле укрепления демократических институтов, корректировки системы сдержек и противовесов, укрепления полномочий парламента и правительства, независимости судебной власти, формирования зрелого гражданского общества.

Однако действия, предпринятые новым президентом РФ В.Путиным, вдохновлялись иными представлениями и осуществлялись в ином направлении. По мнению Т. Карозерса, происходило медленное сползание России к авторитаризму, пагубное для ее настоящего и будущего. «Путин методично выхолостил или прибрал к рукам все основные институты, достигшие хотя бы относительной независимости, в частности, общенациональные вещательные СМИ, Думу, политические партии и региональные власти», - полагает автор ${ }^{16}$. Систематический демонтаж нарождающейся демократической системы в России является, по его мнению, примером де-демократизации, любопытный как для политологов, так и для будущих диктаторов.

Тренд, отмеченный американским политологом, действительно имеет достаточно четкое антидемократическое направление. Однако лучшему пониманию природы нового политического режима, формировавшегося в России с приходом к власти В.Путина, способствовал бы отход от прямолинейной дихотомии «авторитаризм - демократия». Как справедливо подчеркивает И.Крастев, «сегодня авторитаризм лучше всего выживает на ничейной земле - между демократией и авторитарностью» ${ }^{17}$. По его мнению, Россия не является законодателем возвращающейся моды на авторитаризм, который здесь выглядит «скучным и пресным» по сравнению с динамичным китайским. Между тем именно

\footnotetext{
15 Л. Шевцова, Политические зигзаги посткоммунистической России, Москва 1997; Л. Шевцова, Режим Бориса Ельцина, Москва 1999: И. Клямкин, Л. Шевцова,Внесистемный режим Бориса II: некоторые особенности политического развития постсоветской России, Москва 1999.

16 Т. Карозерс, указ статья, с. 75.

17 И. Крастев, Парадоксы нового авторитаризма, „Proetcontra” 2011, № 3-4 (52), с. 101.
} 
развитие России в 1990-е годы породило надежды на всемирное продвижение демократии, а последующий провал демократического процесса в России в 2000х годах заставил многих изменить свое мнение о перспективах глобальной демократической революции. «Поэтому, чтобы понять, куда движется мир, нам, возможно, гораздо важнее прояснить природу путинского авторитаризма, нежели определять источники популярности и успехов авторитарного Китая», - считает И.Крастев ${ }^{18}$.

Оценки режима, дававшиеся российскими и зарубежными исследователями, наглядно отражали его собственную эволюцию. Чаще всего его именовали «гибридным режимом» (Л.Шевцова, И.Клямкин), подчеркивая причудливое сочетание различных элементов, часто неорганичных друг другу. С другой стороны, лояльные власти аналитики (В.Третьяков, С.Марков) предложили концепт «управляемой демократии», смысл которой заключался в том, чтобы предоставить власти возможность «поправлять» результаты свободных выборов в целях сохранения политической стабильности. Напротив, независимые исследователи заговорили об «авторитарной демократии» (В.Рукавишников); «полудемократии» (Л.Гордон); «фасадной демократии» (Д.Фурман); «электоральной демократии» (Л.Даймонд); «электорально-клановой демократии» (А.Лукин); «дефектной демократии» (В.Меркель, А.Круассан) $)^{19}$.

Особый смысл имела концепция «суверенной демократии», предложенная зам. главы президентской администрации В.Сурковым. По мнению Д.Тренина, наряду с сохранением претензий на построение специфически российской разновидности демократии, стабильность которой держится не на институтах, а на доверии граждан своим лидерам, эта концепция посылала сигнал Западу: «мы не ниже вас и не хуже вас». Что касается ролевой модели, то этот сигнал означал, что в мире есть только две полноценные демократии - США и Россия. Остальные либо недостаточно демократичны, либо недостаточно суверенны ${ }^{20}$. Эта позиция затем получила закрепление в Мюнхенской речи В.Путина (2007 г.), в которой Западу фактически был брошен геополитический вызов и неприкрытое стремление вернуть международные отношения в Ялтинско-Потсдамский мир с фиксированными зонами влияния сверхдержав. Россия претендовала на контроль не только над постсоветским пространством, но и над бывшими восточноевропейскими союзниками ${ }^{21}$.

18 Ibidem, c. 97.

19 Дефектность заключается в том, что неформальные институты и связи подчиняют себе формальные, извращая тем самым смысл демократического политического процесса. Дефектные демократии все чаще движутся в направлении открытых автократий.

20 Cм.: http://www.csociety.ru/wind.php?ID=463547\&soch=1, датаобращения: 18.09.2018.

21 См.: Официальный сайт Президента Российской Федерации, http://archive.kremlin.ru/ appears/2007/02/10/1737_type63374type63376type63377type63381type82634_118097.shtml, датаобращения: 18.09.2018. 
Вместе с тем конкурентоспособность нового российского авторитаризма в плане сохранения им политической стабильности заключалась в его умеренной репрессивности (хотя правозащитники вряд ли согласились бы с характеристикой «вегетарианский»); свободе пользоваться Интернетом, выезжать за границу и заниматься бизнесом (при условии уплаты «коррупционного налога». Постидеологическая природа режима и позиционирование себя в качестве разновидности, а не альтернативы западной демократии, долгое время позволяли ему адаптировать для своих целей некоторые ключевые демократические институты (например, выборы). Сохранению нынешнего нового авторитаризма способствуют две черты, нетипичные для классических авторитарных режимов. Во-первых, открытость границ, позволяющая вынуждать недовольных к отъезду из страны и тем самым - к ослаблению организованного сопротивления режиму ${ }^{22}$. Во-вторых, отсутствие единой идеологии, освобождающее элиты от реформистских иллюзий, а оппозицию - от языка и платформы для формирования идеала, сквозь призму которого режим можно представить неполноценным и подвергнуть давлению снизу. Одновременно отсутствие идеологии страхует новые авторитарные режимы от конфронтации с внешним миром, если последние не стремятся экспортировать свои политические модели или навязывать их другим странам.

Вместе с тем выживание режима не означает его социально-экономической успешности: социологические данные показывают, что россияне на протяжении ряда лет выражают недовольство положением дел в стране и чаще всего оценивают последнее как новый застой. Растет число тех, кто полагает, что Россия движется по неверному пути: в ноябре 2018 г. так считали $42 \%$ россиян ${ }^{23}$. Одновременно противоречивый характер российского авторитаризма - стабильность и неэффективность, открытость и отсутствие идеологии - способствует его выживанию и затрудняет возможности противостоять ему в политическом поле.

Возвращение В. Путина на пост президента РФ (2012 г.) принесло с собой попытку новой легитимации режима через обращение к традиционным, консервативным ценностям и усилению роли Русской православной церкви в общественно-политической жизни страны. Однако украинский кризис 2014 года, присоединение к России Крыма и военные действия в Донбассе потребовали иного идеологического обоснования и преподносились уже как защита этнических русских повсюду, где бы они ни проживали. Концепт «русского мира», ранее использовавшийся для обозначения духовного единства всех, ценящих русский язык и многовековую культуру России, стал трактоваться преимуще-

22 «Число российских граждан с видом на жительство в зарубежных странах достигло почти 4 млн человек, причем значительная их часть приобрела за границей жилье и имеет источники дохода» (В. Иноземцев,Перспективы развития России в новом политическом иикле, „Политические исследования” 2012, № 3, с. 8).

23 CM.: https://www.znak.com/2018-11-29/mneniya_rossiyan_o_pravilnosti_puti_po_kotoromu_ idet_strana_razdelilis_pochti_porovnu, датаобращения: 19.09.2018. 
ственно в этническом ключе. Внутри России это способствовало формированию так называемого «крымского консенсуса», базировавшегося не только на идее восстановления «исторической справедливости», но и на благородном мотиве защиты населения Крыма и Донбасса от угрожающих его безопасности и самой жизни украинских националистов («бандеровцев»). Резко критическая реакция западных стран на это решение была преподнесена населению как доказательство извечной враждебности Запада, его корыстных интересов и намерений в отношении России, сорванных решительными действиями российского руководства, прежде всего, президента. Эти события привели к тому, что в российском публичном пространстве появились и стали умножаться следующие авторитарные черты: открытый отказ от либеральных ценностей; попустительство шовинизму, лишь слегка декорированному патриотизмом; сосредоточение в руках государства мощной пропагандистской машины, нацеленной не на информирование, а на программирование мышления и поведения; травля меньшинств, в том числе сексуальных, в угоду маргинальному сознанию; подавление независимого правосудия и формирование репрессивной правоохранительной системы (разной степени жесткости); исподволь складывающийся культ личности вождя ${ }^{24}$.

Благоприятным фоном для упрочения указанной тенденции служит психологический фактор, а именно мечта об историческом реванше, присущая как влиятельной части правящего класса, особенно «силовикам», так и широким слоям населения, преимущественно малых городов и сел России, а также моногородов (в терминологии Н.Зубаревич, «второй» и «третьей» России) ${ }^{25}$. Последние, с одной стороны, материально заинтересованы в том, чтобы получать от государства оборонный заказ и тем самым сохранять занятость и рабочие места, а с другой стороны, податливы на пропагандистские усилия властей по демонстрации патриотизма, державности и т.п. Создание образа врага и сопровождающая его милитаризация сознания способствуют политическому неоизоляционизму, формированию психологии «осажденной крепости».

Эти тенденции в немалой степени скорректировали оценки сегодняшнего политического режима как правопопулистского авторитаризма, опирающегося одновременно на инкорпорированную олигархию и патерналистский конструкт «простого человека» с его традиционными и патриотическими ценностями. Политический миф режима строится на том, что единству лидера и нации «простых патриотических людей» угрожает союз внешних сил и их внутренний агент - образованные и прозападнически настроенные элиты.

24 В. Пастухов, Завтра для России может наступить вот-вот,www.novayagazeta.ru/ politics/61737.htm/, датаобращения:20.09.2018.

25 См.: Н. Зубаревич,Пространство России после Крыма и на фоне кризиса, „Proetcontra” 18.08.2014, с. $118-128$. 
На смену «старому» авторитаризму, как правило, деидеологизированному, пришли активные пропагандистские кампании, в которых эксплуатируются темы консервативных ценностей: приоритет государства перед личностью; православие как источник ценностного консенсуса; сплочение различных слоев и групп вокруг лидера ${ }^{26}$. Активно задействована политика памяти, эксплуатирующая подвиг советского народа в Великой Отечественной войне как символический ресурс легитимации современных внешнеполитических практик. Предпринимаются попытки разыграть карту этнического национализма (через концепт "русского мира» и защиту русских и православных в местах их компактного проживания; через дискуссии о «государствообразующем народе»).

Во внешнеполитическом плане разрабатываются прожекты самоизоляции, самообеспечения, «подлинного суверенитета» (импортзамещение) и т.д. Отсюда же откровенно антизападные пропагандистские кампании вкупе с попытками предстать в роли «подлинной демократии», «подлинной Европы» и «подлинного христианства», «православных основ подлинной российской культуры». В целях достижения главной геополитической задачи - возврата в Ялтинско-Потсдамский мир и раздела сфер влияния между сверхдержавами - внешняя политика все больше испытывается на прочность весьма рискованными импровизациями.

Результирующей такого политического стиля становится формирование нового политического порядка, получившего солидарную оценку исследователей как неопатримониализм ${ }^{27}$. Зарождение этого порядка исследовал руководитель Левада-центра Л.Гудков, отмечая, что на месте относительно целостной бывшей (тотальной) советской системы возникло множество частных, корпоративных и групповых образований со своими частными, корпоративными и групповыми целями и интересами. Попытки восстановить централизованную систему власти (но без политики террора и принуждения) не дают ожидаемого эффекта потому, что в игру вступили клановые и ведомственные интересы, заставляя Кремль торговаться или считаться с теми, кто представляет эти интересы ${ }^{28}$.

С другой стороны, сами представители режима склонны рассматривать себя в качестве корпорации, чему способствует отсутствие у них какой-либо реальной идеологии. «Стремясь всеми силами оставаться у власти, они пытаются ис-

26 См.: А. Глухова, Неотрадиционализм как ресурс политической мобилизацзии, [в:] Разум на распутье: Общественное сознание между прошлым и будущим: Сборник научных статей, ред. Ю.А.Красина (отв.ред.), А.Б.Вебера, А.А.Галкина, Москва 2017, с. 179-191.

27 А. Фисун,К переосмыслению постсоветской политики: неопатримониальная интерпретация,„Политическая концептология: журнал метадисциплинарных исследований” 2010, № 4, с. 158 - 187; Н. Розов, Теории трансформации политчческих режимов и природа неопатримониализма, „Политические исследования” 2015, № 6, с. 157 172; В. Мартьянов,Российский политический порядок в рентно-сословной перспективе,„Политические исследования” 2016, № 4, с. 81-99.

28 См.: Л. Гудков, Природа путинизма, „Вестник общественного мнения”,июль - сентябрь 2009 г., с. 6-21. 
коренить само понятие общественного интереса, - считает И.Крастев. - Если общественный интерес - это не более чем сумма нецеленаправленного сложения частных интересов миллионов людей, то любые жертвы во имя общественных интересов становятся напрасными» ${ }^{29}$. Отсутствие единой идеологии, помимо прочего, означает отказ от предъявления обществу масштабного проекта «лучшего будущего», значимых общественных ориентиров, кроме намерения сохранить статус-кво. Нет притягательной картины завтрашнего дня, в которую должно поверить не только население, но и сами элиты. Однако справиться с такой задачей при помощи простых политтехнологических решений невозможно, а иных способов нет: в обществе отсутствуют публичные механизмы политического целеполагания, опирающиеся на консенсус общественных интересов и стремлений, а соответственно, и их представительство в каких-либо устойчивых формах.

Приватизация государства, публичных должностей и полномочий приводит к тому, что они становятся источником ренты для должностных лиц, которой они делятся с теми, кто наделил их частным правом на государство. «Такова траектория эволюции политического порядка обществ, в которых не сложились ни рациональная национальная бюрократия, независимая от политических элит, ни публично-правовые институты принятия политических решений, - считает В.Мартьянов. - Соответственно становятся невозможны и сами модерные процедуры открытой, рациональной легитимации элит и принимаемых ими решений $\aleph^{30}$. Патримониальным режимам остается лишь развивать своеобразную модель рентно-сословной легитимации, связанной с обеспечением доступа разных сословий к определенным уровням и объемам ренты в обмен на лояльность. В результате происходит подмена механизмов реального волеизъявления и консолидации общества его паллиативной мобилизацией вокруг власти, где мобилизация заменяет модернизацию, превращая ее из стратегии реформ в способ легитимации статус-кво.

В плане идеологического обоснования российский патримониализм опирается на эклектический популизм, сочетание компенсаторского национализма («возрождающейся сверхдержавы»), имитационного традиционализма и риторики модернизации. «Адаптация к переменам происходит не через усложнение состава и структуры общества, увеличение ценностного и культурного многообразия, нарастание человеческого и интеллектуального потенциала, а, напротив, через его снижение и упрощение институтов, обеспечивающих базовые правила взаимодействия в социуме», - считает Л. Гудков ${ }^{31}$. Подобное институциональное

${ }^{29}$ И. Крастев,указ статья, с. 103.

30 В. Мартьянов, Российский политический порядок в рентно-сословной перспективе,„Полис. Политические исследования" 2016, № 4, с. 86.

31 Л. Гудков, Инериия пассивной адаптации, „Proetcontra”,январь - апрель 2011г., с. 38. 
упрощение базовых правил и снижение интеллектуального потенциала общества достигается посредством популистских приемов и стратегий.

Особую роль играет фактор лидера. В отличие от Б. Ельцина, В. Путин умело использовал СМИ для формирования личностного почитания - здесь и верховая езда с обнаженным торсом, и байкерские пробеги и т.п. По мнению П. Ратленда, этот пример иллюстрирует личное управление в обход официальных государственных институтов, а также соответствует образу действия мировых лидеров - популистов, представляющихся «людьми из народа», работающих против истеблишмента и готовых нарушать правила, чтобы служить, по их заверениям, потребностям нации ${ }^{32}$. На медийный компонент как центральный элемент в имидже и поддержании рейтинга популярности В. Путина обращали внимание и российские исследователи ${ }^{33}$. По мнению Л.Гудкова, не наличие программы, идей или убеждений делают В.Путина коллективным символом власти, а как раз их значимое и демонстративное отсутствие обеспечивает массовое признание его в качестве «своего» в сочетании с захватывающей силой показного «права» на принуждение. «Вульгарный социально-политический и националистический популизм лишь дополняет этот образ» ${ }^{34}$.

В этом плане показательны результаты, характеризующие нынешнее состояние внутренней российской политики. Отмечаемое некоторыми авторами возросшее внимание властей к социальной сфере, выделение значительных средств для волонтерской деятельности социально ориентированных НКО в действительности не имеет однозначных трактовок. Майские указы президента Путина 2012 г., создавшие гигантскую нагрузку на региональные бюджеты, ясно свидетельствуют о том, что власть боится массовой протестной мобилизации и блокирует ее на путях патернализма, «отеческой» заботы о народе и т.д. Эта стратегия преследует цель сохранить основания консенсуса, существовавшего в 2000-е годы: забота власти о росте благосостояния граждан в обмен на их политическую лояльность и отказ от активной политической деятельности. Сейчас финансовые ресурсы на продление консенсуса резко сократились, поэтому его пытаются сохранить через расширение активности в социальной сфере. Отсюда шаги навстречу активным общественным структурам как социальному клапану конвертации социальной энергии в достижение «мирных целей».

Иная ситуация - в политической сфере. Целая серия запретительных законов, принятых депутатами Государственной думы VI созыва, демонстрирует, как политическая система «капсулируется»(А.Соловьев), становится все более ригидной, не способной обеспечить динамическую стабильность, т.е. содейство-

32 См.: П. Ратленд, Постсоветские элиты России, „Полис. Политические исследования” 2016, № 3, с. 60 .

33 Л. Гудков, Природа «путинизма», „Вестник общественного мнения. Данные. Анализ. Дискуссии", Июль - сентябрь 2009 г., с. 6-21.

34 Ibidem, c. 9. 
вать развитию общественной системы при сохранении ее устойчивости ${ }^{35}$. Более того, по мнению Л.Гудкова, она не просто консервативна (сопротивляется изменениям, не способна к инновациям); «это институт, одна из функций которого (смысл его деятельности) - сдерживание, блокирование или даже парализация развития других подсистем общества, включая экономику, науку, образование, коммуникации, гражданское общество, публичную сферу жизни... Сегодня речь уже идет не о новом застое, а о нарастающих явлениях социальной и культурной деградации страны, вызванных подавлением процессов модернизации» ${ }^{36}$.

Особую роль играют так называемые вето-игроки, т.е. мощные, хорошо финансируемые группы интересов, создающие проблемы в реализации правительством программы обеспечения общего блага. Происходит коррупционный «захват государства» правящими политико-экономическими группировками, приватизирующими публичную власть и использующими все ее принудительно-властные полномочия для достижения своих корыстных целей ${ }^{37}$. Но безответственная бюрократия и отсутствие инноваций - это признаки нездоровья политической модели, в которой исчезло целеполагание ${ }^{38}$. Социальное положение, вытесняющее во многих странах другие водоразделы - расовые, этнические, гендерного равенства и т.д. - в предвыборной президентской кампании 2018 г. почти не звучало. При этом социальная справедливость по-прежнему устойчиво лидирует в перечне ценностей, наиболее значимых для россиян ${ }^{39}$.

35 Федеральный закон № 121 от 20.06 .2012 г. «О внесении изменений в отдельные законодательные акты Российской Федерации в части регулирования деятельности некоммерческих организаций, выполняющих функции иностранного агента»,http://www/ consultant.ru/document/cons_doc_LAV_132900/ (датаобращения: 12.10.2018).; Федеральный закон от 26.09.1997 N 125-ФЗ «О свободе совести и о религиозных объединениях» „Российская газета”, N 190, 01.10.1997;Федеральный закон от 29.06.2013 N 136-Ф3 «О внесении изменений в статью 148 Уголовного кодекса Российской Федерации и отдельные законодательные акты Российской Федерации в целях противодействия оскорблению религиозных убеждений и чувств граждан», «Собрание законодательства РФ», 01.07.2013, N 26): Федеральный закон от 25.07.2002 N 114-Ф3 «О противодействии экстремистской деятельности», „Российская газета", N 138-139, 30.07.2002.

36 Л. Гудков, Природа «путинизма»,„Вестник общественного мнения. Данные. Анализ. Дискуссии", № 3 (101), 2007, с. 6-21.

37 См.: Ю. Нисневич, Современный авторитаризм и коррупция, „Мировая экономика и международные отношения" 2017, том 61, № 1, с. 108-120. Автор считает отличительной чертой современных неоавторитарных режимов динамическую взаимосвязь принуждения и коррупции.

38 Достаточно обратиться к парламентским выборам 2016 г. или президентским выборам 2018 г., чтобы убедиться в том, что актуальная повестка была выхолощенной и скучной.

39 См.: О чем мечтают россияне: идеал или реальность, ред. М.К.Горшков, Р.Крумм, Н.Е.Тихонова, Москва 2013; М.К.Горшков и др., Российское общество и вызовы времени. Книга вторая(отв. ред. Горшков М.К., Петухов В.В.), Москва 2015, с. 294. 


\section{Critical Yuncture нового российского авторитаризма}

2018 год стал очередной вехой в эволюции нового авторитаризма в России. В.Путин выиграл президентские выборы с большим преимуществом, продемонстрировав не столько политтехнологическое, сколько политическое превосходство над своими соперниками.Основой его курса стали три своеобразные карты: «версальский синдром», т.е. политика обид, связанная с распадом СССР; культ стабильности, т.е. страх перемен, подпитываемый воспоминаниями о тяжелых 1990-х годах; неприятие «европейского выбора», т.е. капитализма и частной собственности ${ }^{40}$. Устранив элиты из политического процесса, В.Путин связал свою власть напрямую с массами, обеспечив их нерушимую сцепку с лидером.

Однако принятие непопулярных мер, касающихся, в первую очередь, социальной сферы (повышение НДС, пенсионная реформа, налог на самозанятых и прочие фискальные меры) привело к заметной потере его популярности. Одновременно принятые меры свидетельствуют о сокращении ресурсов властвования, а, следовательно, и о расторжении негласного контракта, существовавшего до недавнего времени между властью и обществом. К обнулению контракта привело, в первую очередь, повышение пенсионного возраста, вызвавшее резкое неприятие населения России ${ }^{41}$. Как показали результаты региональных выборов 2018 г., поддержка «Единой России», инициировавшей реформу, заметно сократилась, а в четырех регионах РФ ставленники «партии власти» потерпели болезненное поражение. Рейтинги политических и государственных институтов, заметно снижавшиеся в оценках россиян (за исключением личного рейтинга В.Путина и такого института, как армия) ${ }^{42}$, в 2018 году продемонстрировали еще большее падение, затронув на этот раз и рейтинг президента ${ }^{43}$. Появляются зримые свидетельства того, что общество постепенно обретает политическую субъектность: за последний год доля россиян, ощущающих полную или частичную ответственность за происходящее в стране, выросла втрое: с 9\% до $28 \%$. Вместе с тем только $10 \%$ опрошенных считают себя способными влиять на происходящее, тогда как $62 \%$ утверждают, что в масштабах страны ни на что повлиять не могут ${ }^{44}$. Следовательно, готовность россиян к проявлению гражданской активности растет, но в условиях ограниченности легальных каналов выхода последней в обществе постепенно накапливается политическое напряжение. Отмеченная В.Путиным в 2012 г. неспособность политической системы

40 См.: В. Пастухов,Три президентские картыь, „Новая газета”, 31. 03. 2018 г.

41 По данным Левада-центра, около $80 \%$ россиян резко отрицательно относятся к пенсионной реформе. См.: http://www.levada.ru/2018/07/05/pensionnaya-reforma-3/, датаобращения: 14.10.2018.

42 В. Петухов. Кризисная реальность и возможность политической трансформации российского общества,„Политические исследования”, 2016, № 5,c. 9-11.

43 См.: https://www.levada.ru/indikatory/odobrenie-organov-vlasti/, (датаобращения: 07.11. 2018)

44 См.: https://www.levada.ru/2018/10/31/otvetstvennost-rossiyan-za-proishodyashhee-v-stranevyrosla/, датаобращения: 14.10.2018. 
«вместить возросшую политическую активность масс» ${ }^{45}$ в нынешних условиях становится еще более очевидной. По мнению ряда исследователей (Л.Шевцова, Р.Бэккер и др.), российская политическая система приближается к точке бифуркации, признаки которой все чаще просматриваются в потере управляемости на разных уровнях и, как следствие, в снижении эффективности. Вместе с тем вопрос о том, каким именно будет выход из этой точки, остается открытым.

Если обратиться к предложенной немецкими авторами модели «критического момента» (CriticalYuncture) в эволюции авторитарного режима, то его дестабилизация осуществляется в два этапа. На первом этапе происходит продолжительное ослабление каждой из трех его опор. Во-первых, слабеет признание населением режима как правомочного, которому следует подчиняться, происходит его делегитимация. Во-вторых, сокращаются выгоды от кооптации с руководством режима для различных элитных групп, вследствие чего они начинают выстраивать собственные стратегии спасения, включая отказ в лояльности. В-третьих, ослабевает боязнь жестких санкций за противодействие режиму со стороны оппозиционных партий и движений.

На втором этапе теряется компенсационная способность этих трех опор по отношению друг к другу: они больше не добавляют друг другу выгоды, не стабилизируют друг друга. Изменения в одной опоре могут негативно повлиять на другие, если они ведут к понижению комплиментарности ${ }^{46}$. В случае, если отдельные опоры режима теряют связывающую их силу и не могут компенсировать это ослабление при помощи остающихся опор, автократический режим вступает в критический момент (CriticalYuncture), характеризующийся сокращением структурных принуждений - экономических, культурных, идеологических, организаторских и т.д. ${ }^{47}$

Насколько нынешний российский режим приблизился к этому «критическому моменту» пока сказать сложно. Требуется тщательный анализ как предпринимаемых решений и действий режима, так и реакции на них общества. Очевидно лишь, что старые приемы и технологии, исправно служившие режиму на протяжении последних почти двух десятилетий, теряют свою силу, поскольку не соответствуют новой ситуации. Сокращение материальных ресурсов вкупе с усталостью общества от милитаристской истерии разрушают основы легитимности режима, подтверждая неустойчивость харизматической легитимации и неэффективность опоры на сакральную традицию ${ }^{48}$. Горизонтальная лояльность элитных групп (внутриэлитный консенсус) разрушается вследствие потери ма-

45 См.: Владимир Путин,Демократия и качество государства,„Коммерсант”, 06.02.2012 г.

46 См.: J. Gerschewski i in., op. cit., s. 12.

47 Ibidem, s. 17.

48 По данным Левада-центра, в ноябре 2018 г. 61\% россиян считали, что президент России В.Путин в полной мере несет ответственность за все, происходящее в стране. См.: https:// www.znak.com/2018-11-22/levada_centr_dve_treti_rossiyan_schitayut_shto_v_problemah_ strany_vinovat_putin, дата обращения: 16.12.2018. 
териальной выгоды от кооптации с правящим режимом и рисками санкционного давления извне. Привилегированный статус бенефициаров, т.е. государственных корпораций, страхующих свои риски за счет бюджета, не оставляет никаких шансов всем остальным. Рост массового недовольства создает благоприятную атмосферу для активизации деятельности несистемной оппозиции и повышает риски использования силы со стороны власти для прямого подавления политических противников. Определить исход такой стратегии режима непросто: в условиях разбалансированности системы управления и внешнего (санкционного) давления результаты применения силы могут иметь для режима катастрофические последствия.

Отдельным фактором риска становится региональная политика: стремление Центра любой ценой провести к победе на региональных выборах своих кандидатов, игнорируя мнение населения, возрождает имперскую стратегию, осуществлявшуюся в 2014-2017 гг. и вызывавшую резкое недовольство местных элит. Сегодня эта стратегия вошла в резонанс с недовольством населения текущей экономической ситуацией и пенсионной реформой. По мнению К.Рогова, метрополия (Москва) может игнорировать мнение населения, опираясь на поддержку региональных элит, или игнорировать местные элиты, опираясь на поддержку населения (как это было в 2015-2017 гг.). «Но очень трудно игнорировать и тех, и других - и население, и региональные элиты. Это чревато»

\section{Выводы}

Главная проблема любой авторитарной власти, постепенно привыкающей к своей безальтернативности и инструментальной эффективности, заключается в утрате рычагов управления ситуацией, когда политическое пространство приходит в движение. В России так называемая системная оппозиция, материально зависимая от власти, не может предоставить ей адекватную картину социальных нужд. Разрушенные институты коммуникации и диалога между властью и гражданским обществом не способны выполнять модераторскую функцию в назревших общественных конфликтах. Полное отсутствие «образа будущего», превратившегося в проект вечной консервации «настоящего», обрекает власть лишь на два плохих варианта развития событий: либо к полноценному жесткому авторитаризму и репрессиям, либо к медленному саморазрушению под натиском обострённого запроса на перемены. Для реализации второго сценария (как более приемлемого для общества) необходимо созревание социальной базы протеста, взросление реальной оппозиции, набирающейся опыта, а также исчерпание способности режима к адаптации и гибкости. Признаки последнего налицо: положительно трактовавшаяся в последние годы «технократичность» власти в реальности превратилась в медленное окостенение политического организма,

49 К. Рогов,Трещина, https://blog.newsru.com/article/06nov2018/treshina,дата обращения: 07.11.2018. 
Pobrane z czasopisma Wschód Europy http://journals.umcs.pl/we

Data: 26/04/2023 17:00:15

Новый авторитаризм в XXI веке: мировые тенденции и российский case study

устающего от чрезмерной политической подвижности и ищущего все более комфортное положение для своего политического «корпуса». Однако время и условия для такого комфорта, похоже, уходят безвозвратно.

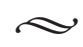

\begin{abstract}
Аннотация: Целью статьи является анализ нового авторитаризма как феномена первой четверти XXI века, имеющего известное сходство с классическими авторитарными режимами прошлых эпох, но и существенные различия с ними. Автор фиксирует рост авторитарных тенденций в современном мире и обусловленные этим попытки исследователей теоретически осмыслить феномен нового авторитаризма, включая его природу, благоприятствующие ему факторы, а также причины его устойчивости и риски дестабилизации. Автор приводит предостережения выдающихся интеллектуалов (Р.Дврендорфа, С.Хантингтона) от недооценки «крадущегося авторитаризм» как современной формы угрозы демократии и свободе, как ограничения либеральных порядков. В статье выявлены факторы, способствующие авторитарному тренду, а также характерные черты нового авторитаризма - антиплюрализм, ограничение свободной политической деятельности, поощрение ксенофобии и т.д. Представлен российский кейс-стади: этапы формирования нового авторитаризма в России в 1990-е - 2000-е годы, его специфический современный облик (неокорпоративизм, державность, культивирование традиционных ценностей и образа врага в лице Запада и т.д.). С опорой на теоретическую модель «критического момента» (Critical Yuncture) показаны уязвимые стороны неоавторитарного режима, создающие для него риски дестабилизации.
\end{abstract}

Ключевые слова: новый авторитаризм; архаика; антиплюрализм; факторы стабильности; риски дестабилизации; Россия; неокорпоративизм; державность; традиционные ценности; правящая элита; «критический момент» (Critical Yuncture).

\title{
Nowy autorytaryzm w XXI wieku: światowe trendy oraz rosyjskie studium przypadku
}

Streszczenie: Celem artykułu jest analiza nowego autorytaryzmu jako fenomenu pierwszej ćwierci XXI wieku, który wykazuje pewne podobieństwa do klasycznych reżimów autorytarnych z minionych epok, ale także znacznie się od nich różni. Autor odnotowuje wzrost tendencji autorytarnych we współczesnym świecie, a co za tym idzie zwiększenie zainteresowania wśród badaczy fenomenem nowego autorytaryzmu, w tym jego natury, sprzyjających mu czynników, a także przyczyn jego stabilności i ryzyka destabilizacji. Przytacza ostrzeżenia wybitnych intelektualistów (R. Dwrendorf, s. Huntington) przed niedocenianiem „pełzającego autorytaryzmu” jako nowoczesnej formy zagrożenia dla demokracji i wolności oraz ograniczenia liberalnych porządków. Artykuł identyfikuje czynniki przyczyniające się do trendu autorytarnego, a także cechy charakterystyczne nowego autorytaryzmu - antypluralizm, ograniczenie swobodnej działalności politycznej, promocję ksenofobii itp. W artykule przedstawiono rosyjskie studium przypadku: etapy powstawania nowego autorytaryzmu w Rosji w latach 90.-2000., jego specyficzny nowoczesny wygląd (neokorporatyzm, suwerenność, kultywowanie tradycyjnych wartości i wizerunek wroga wobec Zachodu itp.). Na podstawie teoretycznego modelu "momentu krytycznego" (Critical Yuncture) wykazano wrażliwe strony reżimu neoautorytarnego, które stwarzają dla niego ryzyko destabilizacji. 
Słowa kluczowe: nowy autorytaryzm, czynniki stabilności, ryzyko destabilizacji, neokorporatyzm, suwerenność, tradycyjne wartości, elita rządząca, „moment krytyczny” (critical yuncture).

\section{New authoritarianism in the XXI century: global trends and Russian case study}

Abstract: The purpose of the research was to analyze the phenomenon of the new authoritarianism in the XXIth century. New authoritarianism has a similarity with the classic authoritarian regimes of past eras, but also it has significant differences with them. The author captures the growth of authoritarian tendencies in the modern world and the resulting attempts of researchers to theoretically comprehend the phenomenon of authoritarianism, including its nature, factors favoring it, as well as the reasons for its stability and the risks of destabilization. The author cites the warnings of prominent intellectuals ( $R$. Darendorf, s. Huntington) against underestimating the "stealing authoritarianism" as a modern form of a threat to democracy and freedom, as a restriction of the liberal order. The article identifies the factors contributing to the authoritarian trend, as well as the characteristic features of the new authoritarianism: anti-pluralism, restriction of free political activity, spreading xenophobia, etc. The Russian case study shows all the stages of new authoritarianism in the 1990s - 2000s, and its specific modern look (neocorporativism, statehood, the cultivation of traditional values and the image of the enemy represented by the West, etc.) Based on the theoretical model of the "critical moment" (Critical Yuncture), the vulnerable sides of the neo-authoritarian regime are shown, creating for it risks of destabilization.

Keywords: new authoritarianism; archaic; antipluralism; stability factors; destabilization risks; Russia; neocorporativism; state power; traditional values; ruling elite; "Critical moment" (Critical Yuncture).

\section{Источники и литература}

\section{Документы и правовые акты}

Vystupleniye i diskussiya na Myunkhenskoy konferentsii po bezopasnosti. Ofitsial'nyy sayt Prezidenta Rossiyskoy Federatsii, http://archive.kremlin.ru/appears/2007/02/10/1737_type63374type63376type63377type63387type82634_118097.shtml/

Federal'nyy zakon № 121 ot $20.06 .2012 \mathrm{~g}$. «0 vnesenii izmeneniy v otdel'nyye zakonodatel'nyye akty Rossiyskoy Federatsii v chasti regulirovaniya deyatel'nosti nekommercheskikh organizatsiy, vypolnyayushchikh funktsii inostrannogo agenta». http: //www/ consultant.ru/document/cons_ doc_LAV_132900/

Federal'nyy zakon ot 29.06.2013 N 136-FZ "0 vnesenii izmeneniy v stat'yu 148 Ugolovnogo kodeksa Rossiyskoy Federatsii i otdel'nyye zakonodatel'nyye akty Rossiyskoy Federatsii v tselyakh protivodeystviya oskorbleniyu religioznykh ubezhdeniy i chuvstv grazhdan" http://www.pravo.gov.ru, 30.06.2013,"Sobraniye zakonodatel'stva RF", 01.07.2013, N 26, st. 3209,"Rossiyskaya gazeta", N 141, 02.07.2013,"Parlamentskaya gazeta", N 24, 05-11.07.2013)..

Federal'nyy zakon ot 25.07.2002 N 114-FZ (red. ot 23.11.2015)"0 protivodeystvii ekstremistskoy deyatel'nosti" (Pervonachal'nyy tekst dokumenta opublikovan v izdaniyakh "Sobraniye zakonodateI'stva RF", 29.07.2002, N 30, st. 3031,"Parlamentskaya gazeta", N 142-143, 30.07.2002,"Rossiyskaya gazeta", N 138-139, 30.07.2002. 
Pobrane z czasopisma Wschód Europy http://journals.umcs.pl/we

Data: 26/04/2023 17:00:15

Новый авторитаризм в XXI веке: мировые тенденции и российский case study

Federal'nyy zakon ot 26.09.1997 N 125-FZ(red. ot 05.02.2018) "0 svobode sovesti i o religioznykh ob "yedineniyakh" (Pervonachal'nyy tekst dokumenta opublikovan v izdaniyakh "Sobraniye zakonodatel'stva RF", 29.09.1997, N 39, st. 4465, "Rossiyskaya gazeta", N 190, 01.10.1997).

\section{Монографии}

Dahrendorf R.,Versuchungen der Unfreiheit (Die Intellektuellen in Zeiten der Prufung), Munchen 2006.

Gdula M., Nowy autorytaryzm, Warszawa 2018.

Gorshkov M.K. i dr., Rossiyskoye obshchestvo i vyzovy vremeni. Kniga vtoraya (otv. red. Gorshkov M.K., Petukhov V.V), Moskva, 2015.

Khantington S., Tret'ya volna. Demokratizatsiya v kontse XX veka (per. s angl.), Moskva 2003.

Klyamkin I., Shevtsova L., VnesistemnyyrezhimBorisall: nekotoryyeosobennostipoliticheskogorazvitiyapo stsovetskoyRossii, Moskva 1999.

Levitsky S., Way L., Competitive Authoritarianism: Hybrid Regimes after the Cold War, UK2010.

Linz J.J., Totalitarian and Authoritarian Regimes, London2000.

Merkel W., Systemtransformation. Eine Einfuhrung in die Theorie und Empirie der Transformationsforschung, Wiesbaden2010.

O chem mechtayut rossiyane: ideal ili real'nost', red. M.K. Gorshkov, R. Krumm, N.E. Tikhonova, Moskva 2013.

Ottaway M., Democracy Challenged: The Rise of Semi-Authoritarianism, Washington 2003.

Shevtsova L., Politicheskiye zigzagi postkommunisticheskoy Rossii, Moskva 1997.

Shevtsova L., Rezhim Borisa El'tsina, Moskva 1999.

Научныестатьи

Darendorf R., RazmyshleniyaorevolyutsiivEvrope (pis'monekoyemugospodinuvVarshave), „Put'. Mezhdunarodnyy filosofskiy zhurnal" 1994, № 6 .

Fisun A. A., K pereosmysleniyu postsovetskoy politiki: neopatrimonial'naya interpretatsiya, „Politicheskaya kontseptologiya: zhurnal metadistsiplinarnykh issledovaniy" 2010, № 4.

Gerschewski J., Merkel W., Schmotz A., Stefes C., Tanneberg D., Warum uberleben Diktaturen, Politische Vierteljahresschrif, Sonderheft 47, 2012.

GlukhovaA.V., Neotraditsionalizmkakresurspoliticheskoymobilizatsii, [v:] Razumnarasput'ye: Obshchest vennoyesoznaniyemezhduproshlymibudushchim: Sborniknauchnykhstatey, red. Yu.A. Krasina (otv. red.), A.B. Vebera, A.A. Galkina, Moskva 2017.

Gudkov L., Inertsiya passivnoy adaptatsii, „Pro et contra”, yanvar' - aprel' $2011 \mathrm{~g}$.

Gudkov L., Priroda putinizma, „Vestnik obshchestvennogo mneniya. Dannyye. Analiz. Diskussii”, Iyul' sentyabr' $2009 \mathrm{~g}$.

Inozemtsev V., Perspektivy razvitiya Rossii v novom politicheskom tsikle, „Polis. Politicheskiye issledovaniya" 2012, № 3.

Karozers T., Trezvyy vzglyad na demokratiyu, „Pro et contra” 2005, № 1 (28).

Krastev I., Paradoksy novogo avtoritarizma, „Pro et contra” 2011, № 3-4 (52).

Mart'yanov V.S., Rossiyskiy politicheskiy poryadok v rentno-soslovnoy perspektive, „Polis. Politicheskiye issledovaniya" 2016, № 4.

Nisnevich Yu., Sovremennyy avtoritarizm i korruptsiya, „Mirovaya ekonomika i mezhdunarodnyye otnosheniya" 2017, tom 61, № 1. 
Pobrane z czasopisma Wschód Europy http://journals.umcs.pl/we

Data: 26/04/2023 17:00:15

Pastukhov V., Tri prezidentskiye karty, „Novaya Gazeta” 31. 03. 2018.

Petukhov V.V., Krizisnaya real'nost' i vozmozhnost' politicheskoy transformatsii rossiyskogo obshchestva, „Polis. Politicheskiye issledovaniya” 2016, № 5.

Putin V., Demokratiya i kachestvo gosudarstva, "Kommersant” 06.02.2012.

Ratlend P., Postsovetskiye elity Rossii, „Polis. Politicheskiye issledovaniya” 2016, № 3.

Rozov N.S., Teorii transformatsii politicheskikh rezhimov i priroda neopatrimonializma, „Polis. Politicheskiye issledovaniya" 2015, № 6 .

Yazhborovskaya I. S., Pol'sha 2015-2016 gg. Khronika neoavtoritarnogo revansha „Polis. Politicheskiye issledovaniya" 2016, № 5 .

Zubarevich N., Prostranstvo Rossii posle Kryma i na fone krizisa, „Pro et contra”, May - avgust 2014.

Интернет-источники

Levada-Tsentr, Analiticheskiy tsentr Yuriya Levady, https://www.levada.ru

Pastukhov V., Zavtra dlya Rossii mozhet nastupit' vot-vot, https: www.novayagazeta.ru/politics/61737. $\mathrm{htm} /$

Rogov K., Treshchina, https://blog.newsru.com/article/06nov2018/treshina 